\title{
Effect of Microwave on Seed Germination and Plant Growth in Acacia Sp. (Acacia farnesiana and Acacia saligna)

\author{
Hanan E. Ibrahim ${ }^{1}$, Hanan G. El-Fadaliy ${ }^{1}$, Nader A. El-Shanhorey ${ }^{2}$
}

\begin{abstract}
This study was carried-out at Orman Garden, Horticulture Research Institute, A.R.C. Giza, Egypt during the two successive seasons of 2013 and 2014. In this study, we aimed to test the effect of different exposure time from microwave on increasing vegetative growth and chemical constituents in Acacia farnesiana and Acacia saligna seedlings. The seeds have been exposed to the microwave radiation for $0 \mathrm{~s}$ (control), $5 \mathrm{~s}, 10 \mathrm{~s}, 15 \mathrm{~s}, 20 \mathrm{~s}$ and $25 \mathrm{~s}$ in the Acacia farnesiana and seeds have been exposed to the microwave radiation for $0 \mathrm{~s}$ (control), 10s, 20s, 30s, $40 \mathrm{~s}$ and $50 \mathrm{~s}$ in the Acacia saligna in the both seasons respectively. Seedlings were planted individually in $30 \mathrm{~cm}$ diameter plastic pots filled with $8 \mathrm{~kg}$ of mixture of clay and sand at the ratio of $(1: 1)$ by volume. The obtained results revealed that the exposure time from microwave showed that significantly increasing in vegetative growth and chemical constituents. From the obtained results, it could be concluded that the highest mean in Acacia farnesiana plant was scored as a result of exposure time at 5 second. Whereas, it could be concluded that the highest mean in Acacia saligna plant was scored as a result of exposure time at 10 second in the both seasons, respectively.
\end{abstract}

Key words: Acacia farnesiana - Acacia saligna microwave - seeds germination.

\section{INTRODUCTION}

Acacia (Mill.) is the largest genus in the Leguminosae - Mimosoideae with approximately 1,200 species distributed mainly in tropical and subtropical regions (Mabberley, 1997). Multipurpose trees like Acacia sp., which can cope with severe environmental conditions are useful tree species for afforestation in arid and semi-arid areas (Aref, 1996).

The efforts nowadays are directed to choose tree species that can be used for different purposes and have the capability of coping with the prevalent harsh environmental conditions. Many acacias were of those species, which have proved such capability and known as multipurpose trees. In addition, some acacia species are widespread in Egypt and represented by trees and shrubs (Aref, 1996 and 2000). Nevertheless, the main problem encountered using Acacia species in forestation programmers is the poor germination of their seeds. This comes from their seed water impermeable testas, which exerts a physical exogenous dormancy (Holmes et al., 1987). Acacia therefore, will not germinate promptly when placed under condition, which are normally regarded as suitable for germination. Such seeds are said to be dormant. To overcome seed dormancy and obtain rapid and synchronous germination artificially before sowing, the seed must be subjected to some physical or chemical treatments. Such pre-germination treatments will quickly destroy the integrity of impermeable cover and so permit the imbibitions of the embryo. Several artificial methods are used to break the hard impermeable seed coat of acacias. The pretreatment with sulphuric acid for three to fifteen minutes is the method most often used (Cheema and Qadir, 1973 and Roussel, 1984). Other methods which are also recommended are mechanical scarification or ablation of the integument and scalding the seeds in boiling water (Kaul and Manohar, 1966 and Doran et al, 1983). Giffard (1975) recommends a pregermination of twelve to twenty-four hours soaking in water at room temperature, has been studied in several species of the family Leguminosae, For example, according to Gebre and Karam (2004).

A few studies have demonstrated that microwave radiation has a positive effect in accelerating seed germination (Rao et al., 1989, Hu et al., 1996 and Chen et al., 2005). However, regardless of the data concerning the effect of microwaves on plants that have been obtained, little is known as to whether pretreatment of seeds with microwave causes a change in the inner energy of seeds, stimulating enzyme activities, leading to an improvement of the metabolism, and enhancing the intensity of biophoton emission, which is regarded as an index of cell metabolism (Abeles, 1986 and Higeg and Inaba, 1991). Therefore, in the present study, we attempted to assess the effect of a microwave $(12.5 \mathrm{~cm}, 1.26 \mathrm{~mW} / \mathrm{mm} 2)$ on the germinating of Acacia sp. seeds. Therefore, the mechanism of action responsible for the effect of laser irradiation may be through its light and electromagnet effects (Xiang, 1995). To confirm this, we used microwaves $\left(1.26 \mathrm{~mW} / \mathrm{mm}^{2}\right)$ to pretreat seeds and compared their effect in Isatis indigotica.

${ }^{1}$ Ornamental Plants and Landscape Research Department,

Horticulture Research Institute, ARC, Geza, Egypt.

${ }^{2}$ Botanical Gardens Research Department,

Horticultural Research Institute, ARC, Alexandria, Egypt.

Received August 2, 2016, Accepted September 18, 2016 
These plant proteins receive special attention, found that the protein analysis of seeds in Acacia species (Ali, 1994) and (El-Akkad, 2004), RAPD analysis in Acacia species (Rashmi et al., 2004). However, no research has been done in Acacia species for comparison of protein profile in vitro and in vivo. Although, other medicinal plant species were examined for their protein in vivo and in vitro viz. Bacopa monnieri (Mohapatra and Rath, 2005) and (Sharma, 2006).

The present study aims at comparing the effect of short wave treatments on seeds germination and vegetative growth in two Acacia species (Acacia farnesiana and Acacia saligna) grown in Egypt.

\section{MATERIALS AND METHODS}

The present study was carried-out at Orman Research Branch, Horticulture Research Institute, A.R.C. Giza, Egypt during the two successive seasons of 2013 and 2014.

Microwave used in this study were generated from a microwave oven Model-Mo6T, single phase, 220 V., 50 Hs., $1.3 \mathrm{Kw}$ output at a frequency of $2450 \mathrm{MHz}$. Dry seeds were exposed to short waves from microwave on first of February, 2013 and 2014 in the both seasons, respectively. 540 seeds were divided into 6 groups per specie (6 groups* 90 seeds per treatment) and each treatment was put in a bag. The seeds have been exposed to the microwave radiation for $0 \mathrm{~s}$ (control), $5 \mathrm{~s}$, $10 \mathrm{~s}, 15 \mathrm{~s}, 20 \mathrm{~s}$ and $25 \mathrm{~s}$ in the Acacia farnesiana while seeds of Acacia saligna have been exposed to the microwave radiation for $0 \mathrm{~s}$ (control), 10s, 20s, 30s, 40s and $50 \mathrm{~s}$ in the first and second seasons respectively. Groups of 90 seeds were subjected to each microwave treatment, for chosen exposure times and analogous groups were used as control. The Acacia seeds were cultured then in small plastic pots ( $15 \mathrm{~cm}$ diameter), 30 seeds in each pot, on mixture of peat moss and sand at ratio of $1: 1(\mathrm{v} / \mathrm{v})$. The pots were watered daily. On $1^{\text {st }}$ March 2013 and 2014 in the first and second seasons, respectively, the pots were gradually transferred from shade to sunny place along two weeks.

On the $15^{\text {th }}$ of March, 2013 and 2014 (in the first and second seasons, respectively) homogeneous seedlings of Acacia farnesiana and Acacia saligna (20$25 \mathrm{~cm}$ height in average) were planted individually in plastic pots ( $30 \mathrm{~cm}$ diameter) filled with $8 \mathrm{~kg}$ of mixture of clay and sand at ratio of 1:1 (v/v). The chemical constituents of the soil were measured as described by Jackson (1958) as shown in Table (1). On $30^{\text {th }}$ of October in the both seasons, the plants were harvested.
In the two seasons, all plants received NPK chemical fertilization using soluble fertilizer (Kristalon 19-19-19) at the rate of $3 \mathrm{~g} /$ pot. Fertilization was repeated every 30 days throughout the growing season (from the $1^{\text {st }}$ of March till the $30^{\text {th }}$ of October). In addition, weeds were removed manually upon emergence.

\section{Data recorded:}

\section{(1) Seed germination (\%)}

On February 15, 2013 and 2014 in the first and second seasons, respectively, the seeds of every treatment were sown in three trays (90 seeds for each treatment). The seeds were sown in trays containing a soil mixture of 1 sand: 1 peat moss by volume. Germination percentage of every treatment was calculated after 30 days from sowing according to the following formula:

$$
\text { Seed germination } \%=\frac{\text { Number of germinated seed }}{\text { Number of total seeds }} \times 100
$$

\section{(2) Vegetative growth parameters:}

Sprouting date (day), plant height $(\mathrm{cm})$, number of leaves per plant, leaves dry weight per plant $(\mathrm{g})$, stem diameter $(\mathrm{cm})$, stem dry weight $(\mathrm{g})$, root length $(\mathrm{cm})$ and root dry weight (g).

\section{(3) Chemical analysis determination:}

- Pigments content: Chlorophyll a, b and carotenoids were determined in leaf samples ( $\mathrm{mg} / \mathrm{g}$ fresh matter) according to Nornai (1982).

- Total soluble phenols: phenols were determined by using Folin-Denis colorimetric method (A.O.A.C., 1970) and a standard curve of pyrogallol was used.

- Total soluble indoles: indoles were determined colorimetric according to method described by Larson et al. (1962) and modified by Selim et al. (1978) using a standard curve of indole acetic acid (IAA).

- Peroxidase activity: Peroxidase activity was prepared according to the methods described by Howell et al. (2000).

- Protein analysis: Treatments acacia seedlings were used for comparing protein content. For protein estimation these samples were lyophilized, macerated in $80 \%$ ethanol and elucidated by the method of Lowry et al., (1951). 
Table 1. Chemical analyses of the used mixture of clay and sand (1:1) for the two successive seasons 2013 and 2014

\begin{tabular}{lccccccccc}
\hline \multirow{2}{*}{ Season } & \multirow{2}{*}{$\mathbf{p H}$} & $\mathbf{E C}$ & \multicolumn{3}{c}{ Soluble cations (meq/l) } & \multicolumn{3}{c}{ Soluble anions (meq/I) } \\
\cline { 5 - 12 } & & $\left(\mathbf{d S m}^{-\mathbf{1}}\right)$ & $\mathbf{C a}^{++}$ & $\mathbf{M g}$ & $\mathbf{N a}^{+}$ & $\mathbf{K}^{+}$ & $\mathbf{H C O}_{\mathbf{3}}^{-}$ & $\mathbf{C l}^{-}$ & $\mathbf{S O}_{2}^{--}$ \\
\hline 2013 & 7.98 & 1.63 & 3.3 & 3.4 & 6.7 & 1.2 & 3.6 & 6.9 & 2.4 \\
\hline 2014 & 7.94 & 1.58 & 3.1 & 3.0 & 6.5 & 1.1 & 3.3 & 6.7 & 2.2 \\
\hline
\end{tabular}

Electrophoresis has become a useful tool for the characterization of plant proteins. Protein profiles were studied by sodium-dodecyl sulphate polyacrylamide gel electrophoresis (Laemmli, 1970). A vertical slab gel apparatus was as described by Studier (1973). Proteins are treated with sodium dodecyl sulfate (SDS) before electrophoresis so that the charge density of all proteins is made roughly equal. When these samples are electrophoresed, proteins are separated according to mass. The protein bands were visualized by transilluminator and photographs were taken for comparison of results.

The experimental design was a complete randomized block design (RCBD) contained 12 treatments with three replicates; each replicate contained three plants per treatment. Data were subjected to analysis of variance (ANOVA) using the SAS program, SAS Institute (Snedecor and Cochran, 1980) and the mean the values were compared using L.S.D test at 5\% level (SAS Institute, 2002).

\section{RESULTS}

Seed germination (\%)

Data outlined in Table (2) reveal the effect of different exposure time from microwave on seed germination. However, it could be concluded that the highest mean in Acacia farnesiana plant was scored as a result of exposure time at $5 \mathrm{sec} .67 .77$ and $69.99 \%$ in the first and second seasons, respectively. Whereas, it could be concluded that the highest mean in Acacia saligna plant was scored as a result of exposure time at 10 sec. 71.10 and $69.99 \%$ in the first and second seasons, respectively. On the other hand, the lowest means of germination in Acacia farnesiana and Acacia saligna were in control plants in the both seasons.

\section{Vegetative growth}

\section{Sprouting date (day)}

Data outlined in Table (3) reveal the effect of different exposure time from microwave on sprouting date. On most cases, were observed on sprouting date due to using the different exposure time. However, it could be concluded that the lowest mean in Acacia farnesiana plant was scored as a result of exposure time of $5 \mathrm{sec} .13 .50$ and 13.50 day in the first and second seasons, respectively. Whereas, it could be concluded that the lowest mean in Acacia saligna plant was scored as a result of exposure time of $10 \mathrm{sec} .13 .33$ and 13.50 day in the first and second seasons, respectively. On the other hand, the highest means of different exposure time from microwave on sprouting date in Acacia farnesiana and Acacia saligna were in control plants in the both seasons, respectively.

Table 2. Percentage of seeds germination of Acacia farnesiana and Acacia saligna plants as influenced by different exposure times from microwave in the two seasons of 2013 and 2014

\begin{tabular}{|c|c|c|c|}
\hline \multicolumn{2}{|c|}{ TREATMENTS } & \multicolumn{2}{|c|}{ Seeds germination $(\%)$} \\
\hline Species & Exposure time & 2013 & 2014 \\
\hline \multirow{6}{*}{ Acacia farnesiana } & Control & 44.44 & 43.33 \\
\hline & $5 \mathrm{Sec}$. & 67.77 & 69.99 \\
\hline & $10 \mathrm{Sec}$. & 66.66 & 67.77 \\
\hline & $15 \mathrm{Sec}$. & 58.88 & 61.11 \\
\hline & $20 \mathrm{Sec}$. & 53.33 & 54.44 \\
\hline & $25 \mathrm{Sec}$. & 46.66 & 47.77 \\
\hline L.S.D. at 0.05 & & 3.78 & 1.80 \\
\hline \multirow{6}{*}{ Acacia saligna } & Control & 45.55 & 47.77 \\
\hline & $10 \mathrm{Sec}$. & 71.10 & 69.99 \\
\hline & $20 \mathrm{Sec}$. & 64.44 & 64.44 \\
\hline & $30 \mathrm{Sec}$. & 56.66 & 59.99 \\
\hline & $40 \mathrm{Sec}$. & 49.99 & 54.44 \\
\hline & $50 \mathrm{Sec}$. & 49.99 & 49.99 \\
\hline L.S.D. at 0.05 & & 3.44 & 2.47 \\
\hline
\end{tabular}


Table 3. Means of sprouting date (day), plant height $(\mathrm{cm})$, number of leaves per plant and leaves dry weight (g) of Acacia farnesiana and Acacia saligna plants as influenced by different exposure times from microwave in the two seasons of 2013 and 2014

\begin{tabular}{|c|c|c|c|c|c|c|c|c|c|}
\hline \multicolumn{2}{|c|}{ TREATMENTS } & \multicolumn{2}{|c|}{$\begin{array}{c}\text { Sprouting date } \\
\text { (day) }\end{array}$} & \multicolumn{2}{|c|}{$\begin{array}{c}\text { Plant height } \\
(\mathrm{cm})\end{array}$} & \multicolumn{2}{|c|}{$\begin{array}{c}\text { Number of } \\
\text { leaves per plant }\end{array}$} & \multicolumn{2}{|c|}{$\begin{array}{c}\text { Leaf dry weight } \\
\text { (g) }\end{array}$} \\
\hline Species & $\begin{array}{c}\text { Exposure } \\
\text { time }\end{array}$ & 2013 & 2014 & 2013 & 2014 & 2013 & 2014 & 2013 & 2014 \\
\hline \multirow{6}{*}{$\begin{array}{l}\text { Acacia } \\
\text { farnesiana }\end{array}$} & Control & 16.16 & 16.50 & 84.00 & 84.83 & 23.50 & 23.66 & 17.86 & 18.04 \\
\hline & $5 \mathrm{Sec}$. & 13.50 & 13.50 & 87.33 & 88.50 & 24.83 & 24.66 & 18.57 & 18.82 \\
\hline & $10 \mathrm{Sec}$. & 14.33 & 14.33 & 85.33 & 86.16 & 24.00 & 24.00 & 18.15 & 18.33 \\
\hline & $15 \mathrm{Sec}$. & 15.00 & 15.33 & 81.83 & 83.50 & 23.00 & 23.33 & 17.40 & 17.76 \\
\hline & $20 \mathrm{Sec}$. & 15.66 & 16.00 & 77.83 & 79.66 & 22.00 & 22.33 & 16.55 & 16.94 \\
\hline & $25 \mathrm{Sec}$. & 16.50 & 16.50 & 74.50 & 77.16 & 21.00 & 21.66 & 15.84 & 16.41 \\
\hline \multicolumn{2}{|l|}{ L.S.D. at 0.05} & 0.395 & 0.271 & 1.995 & 0.750 & 0.717 & 0.395 & 0.423 & 0.157 \\
\hline \multirow{6}{*}{ Acacia saligna } & Control & 16.50 & 17.00 & 78.25 & 81.50 & 21.66 & 23.00 & 16.64 & 17.33 \\
\hline & $10 \mathrm{Sec}$. & 13.33 & 13.50 & 85.58 & 85.33 & 24.00 & 24.33 & 18.20 & 18.15 \\
\hline & $20 \mathrm{Sec}$. & 14.33 & 14.33 & 82.08 & 83.50 & 23.00 & 23.16 & 17.46 & 17.76 \\
\hline & $30 \mathrm{Sec}$. & 14.66 & 15.00 & 79.08 & 80.66 & 22.33 & 23.00 & 16.82 & 17.15 \\
\hline & $40 \mathrm{Sec}$. & 15.33 & 15.83 & 75.91 & 78.00 & 21.33 & 22.00 & 16.14 & 16.59 \\
\hline & $50 \mathrm{Sec}$. & 16.33 & 16.16 & 72.08 & 74.33 & 20.33 & 21.00 & 15.33 & 15.81 \\
\hline \multicolumn{2}{|l|}{ L.S.D. at 0.05} & 0.439 & 0.395 & 0.866 & 0.481 & 0.395 & 0.287 & 0.182 & 0.102 \\
\hline
\end{tabular}

\section{Plant height (cm)}

Data obtained on the effect of different exposure time on plant height were averaged in Table (3). Clear effect on plant height was noticed as a result of different exposure time. In this connection, it could be concluded that the highest means in Acacia farnesiana plant were scored as a result of exposure time of $5 \mathrm{sec}$. it were 87.33 and $88.50 \mathrm{~cm}$ in the first and second seasons, respectively. Whereas, it could be concluded that the highest means in Acacia saligna plant were scored as a result of exposure time of $10 \mathrm{sec} .85 .58$ and $85.33 \mathrm{~cm}$ in the first and second seasons, respectively. On the other hand, the lowest mean of different exposure time on plant height in Acacia farnesiana and Acacia saligna were at time of $25 \mathrm{sec}$. and $50 \mathrm{sec}$. in the both seasons, respectively.

\section{Number of leaves per plant}

Data obtained on the effect of different exposure time from microwave on number of leaves per plant were averaged in Table (3). The microwave treatments used revealed clear differences on number of leaves per plant. Clear effect on number of leaves per plant was noticed as a result of different exposure time. In this connection, it could be concluded that the highest means in Acacia farnesiana plant were scored as a result of exposure time of $5 \mathrm{sec}$. it were 24.83 and 24.66 in the first and second seasons, respectively. Whereas, it could be concluded that the highest means in Acacia saligna plant were scored as a result of exposure time of $10 \mathrm{sec}$. and were 24.00 and 24.33 in the first and second seasons, respectively. On the other hand, the lowest means of number of leaves per plant in Acacia farnesiana and Acacia saligna were observed at exposure time of $25 \mathrm{sec}$. in the both seasons, respectively.

\section{Leaf dry weight (g)}

Data presented in Table (3) reveal the effect of different exposure time from microwave on leaf dry weight. However, it could be concluded that the highest means in Acacia farnesiana plant were scored as a result of exposure time of $5 \mathrm{sec}$. and they were 18.57 and $18.82 \mathrm{~g}$ in the first and second seasons, respectively. Whereas, it could be concluded that the highest means in Acacia saligna plant were scored as a result of exposure time of $10 \mathrm{sec}$. and they were 18.20 and $18.15 \mathrm{~g}$ in the first and second seasons, respectively. On the other hand, the lowest means of leaf dry weight in Acacia farnesiana and Acacia saligna were at exposure time of $25 \mathrm{sec}$. and $50 \mathrm{sec}$. in the both seasons, respectively.

\section{Stem diameter $(\mathrm{cm})$}

Data obtained on the effect of different exposure time on stem diameter were averaged in Table (4). Clear effect on stem diameter was noticed as a result of different exposure times. In this connection, it could be concluded that the highest means in Acacia farnesiana plant were scored as a result of exposure time of $5 \mathrm{sec}$., where the stem diameter were 0.88 and $0.89 \mathrm{~cm}$ in the first and second seasons, respectively. Whereas, it could be concluded that the highest means in Acacia saligna 
plant were scored as a result of exposure time of $10 \mathrm{sec}$. and the stem diameter was $0.86 \mathrm{~cm}$ in both seasons. On the other hand, the lowest means of stem diameter in Acacia farnesiana and Acacia saligna were recorded at exposure time of 25 and $50 \mathrm{sec}$., respectively, in the both seasons.

\section{Stem dry weight (g)}

Data presented in Table (4) reveal the effect of different exposure times from microwave on stem dry weight. However, it could be concluded that the highest mean in Acacia farnesiana plant was scored as a result of exposure time of $5 \mathrm{sec}$. and they were 9.13 and 9.27 $\mathrm{g}$ in the first and second seasons, respectively. Whereas, it could be concluded that the highest means in Acacia saligna plant was scored as a result of exposure time of $10 \mathrm{sec}$. and they were 8.95 and $8.92 \mathrm{~g}$ in the first and second seasons, respectively. On the other hand, the lowest means of stem dry weights in Acacia farnesiana and Acacia saligna were observed at exposure times of 25 and $50 \mathrm{sec}$. in the both seasons, respectively.

\section{Root length (cm)}

Data obtained on the effect of different exposure times on root length were averaged in Table (4). Clear effect on root length was noticed as a result of different exposure times. In this connection, it could be concluded that the highest mean in Acacia farnesiana plant was scored as a result of exposure time of $5 \mathrm{sec}$. and they were 26.45 and $26.81 \mathrm{~cm}$ in the first and second seasons, respectively. Whereas, it could be concluded that the highest means in Acacia saligna plant was scored as a result of exposure time of $10 \mathrm{sec}$., where the root length reached 25.92 and $25.85 \mathrm{~cm}$ in the first and second seasons, respectively. On the other hand, the lowest means of root length in Acacia farnesiana and Acacia saligna were seen at exposure times of 25 and $50 \mathrm{sec}$. in the both seasons, respectively.

\section{Root dry weight (g)}

Data presented in Table (4) reveal the effect of different exposure times from microwave on root dry weight. However, it could be concluded that the highest means in Acacia farnesiana plant was scored as a result of exposure time of $5 \mathrm{sec}$. and they were 6.00 and 6.10 $\mathrm{g}$ in the first and second seasons, respectively. Whereas, it could be concluded that the highest means in Acacia saligna plant was scored as a result of exposure time of $10 \mathrm{sec}$., where they were 5.89 and $5.88 \mathrm{~g}$ in the first and second seasons, respectively. On the other hand, the lowest means of root dry weight in Acacia farnesiana and Acacia saligna were scored at exposure times of 25 and $50 \mathrm{sec}$. in the both seasons, respectively.

\section{Chemical constituents}

\section{Clorophyll (a) content in fresh weight of leaves (mg/g)}

Data presented in Table (5) reveal the effect of different exposure times from microwave on chlorophyll (a) content in fresh leaves. However, it could be concluded that the highest means in Acacia farnesiana plant were scored as a result of exposure time of 5 sec., where chlorophyll (a) contents were 0.686 and $0.670 \mathrm{mg} / \mathrm{g}$ in the first and second seasons, respectively.

Table 4. Means of stem diameter $(\mathrm{cm})$, stem dry weight $(\mathrm{g})$, root length $(\mathrm{cm})$ and root dry weight (g) of Acacia farnesiana and Acacia saligna plants as influenced by different exposure times from microwave in the two seasons of 2013 and 2014

\begin{tabular}{|c|c|c|c|c|c|c|c|c|c|}
\hline \multicolumn{2}{|c|}{ TREATMENTS } & \multicolumn{2}{|c|}{$\begin{array}{l}\text { Stem diameter } \\
(\mathrm{cm})\end{array}$} & \multicolumn{2}{|c|}{$\begin{array}{l}\text { Stem dry } \\
\text { weight (g) }\end{array}$} & \multicolumn{2}{|c|}{$\begin{array}{l}\text { Root length } \\
\text { (cm) }\end{array}$} & \multicolumn{2}{|c|}{$\begin{array}{c}\text { Root dry weight } \\
\text { (g) }\end{array}$} \\
\hline Species & Exposure time & 2013 & 2014 & 2013 & 2014 & 2013 & 2014 & 2013 & 2014 \\
\hline \multirow{6}{*}{$\begin{array}{l}\text { Acacia } \\
\text { farnesiana }\end{array}$} & Control & 0.85 & 0.85 & 8.78 & 8.88 & 25.44 & 25.70 & 5.77 & 5.83 \\
\hline & 5 Sec. & 0.88 & 0.89 & 9.13 & 9.27 & 26.45 & 26.81 & 6.00 & 6.10 \\
\hline & $10 \mathrm{Sec}$. & 0.86 & 0.87 & 8.93 & 9.01 & 25.85 & 26.10 & 5.86 & 5.91 \\
\hline & $15 \mathrm{Sec}$. & 0.83 & 0.85 & 8.56 & 8.73 & 24.79 & 25.40 & 5.62 & 5.76 \\
\hline & $20 \mathrm{Sec}$. & 0.78 & 0.80 & 8.14 & 8.33 & 23.58 & 24.13 & 5.35 & 5.47 \\
\hline & $25 \mathrm{Sec}$. & 0.75 & 0.78 & 7.79 & 8.07 & 22.56 & 23.37 & 5.12 & 5.30 \\
\hline \multicolumn{2}{|c|}{ L.S.D. at 0.05} & 0.019 & 0.009 & 0.209 & 0.095 & 0.604 & 0.241 & 0.135 & 0.070 \\
\hline \multirow{6}{*}{$\begin{array}{l}\text { Acacia } \\
\text { saligna }\end{array}$} & Control & 0.79 & 0.82 & 8.18 & 8.52 & 23.70 & 24.72 & 5.37 & 5.61 \\
\hline & $10 \mathrm{Sec}$. & 0.86 & 0.86 & 8.95 & 8.92 & 25.92 & 25.85 & 5.89 & 5.88 \\
\hline & 20 Sec. & 0.83 & 0.85 & 8.58 & 8.75 & 24.86 & 25.30 & 5.64 & 5.78 \\
\hline & 30 Sec. & 0.80 & 0.82 & 8.27 & 8.44 & 23.96 & 24.43 & 5.44 & 5.56 \\
\hline & $40 \mathrm{Sec}$. & 0.76 & 0.79 & 7.94 & 8.17 & 23.00 & 23.62 & 5.22 & 5.36 \\
\hline & $50 \mathrm{Sec}$. & 0.72 & 0.74 & 7.54 & 7.77 & 21.83 & 22.51 & 4.96 & 5.11 \\
\hline \multicolumn{2}{|c|}{ L.S.D. at 0.05} & 0.011 & 0.006 & 0.088 & 0.068 & 0.264 & 0.156 & 0.060 & 0.041 \\
\hline
\end{tabular}


Table 5. Means of chlorophylls and carotene content of Acacia farnesiana and Acacia saligna plants as influenced by different exposure times from microwave in the two seasons of 2013 and 2014

\begin{tabular}{|c|c|c|c|c|c|c|c|}
\hline \multicolumn{2}{|l|}{ TREATMENTS } & \multicolumn{2}{|c|}{$\begin{array}{c}\text { Chlorophyll (A) } \\
\text { content }(\mathrm{mg} / \mathrm{g} \text { FW) }\end{array}$} & \multicolumn{2}{|c|}{$\begin{array}{c}\text { Chlorophyll (B) } \\
\text { content (mg/g FW) }\end{array}$} & \multicolumn{2}{|c|}{$\begin{array}{c}\text { Carotene content } \\
(\mathrm{mg} / \mathrm{g} \text { FW })\end{array}$} \\
\hline Species & Exposure time & 2013 & 2014 & 2013 & 2014 & 2013 & 2014 \\
\hline \multirow{6}{*}{ Acacia farnesiana } & Control & 0.634 & 0.641 & 0.335 & 0.337 & 0.452 & 0.457 \\
\hline & $5 \mathrm{Sec}$. & 0.686 & 0.670 & 0.360 & 0.352 & 0.489 & 0.478 \\
\hline & $10 \mathrm{Sec}$. & 0.654 & 0.653 & 0.344 & 0.343 & 0.466 & 0.466 \\
\hline & $15 \mathrm{Sec}$. & 0.638 & 0.633 & 0.335 & 0.333 & 0.455 & 0.451 \\
\hline & $20 \mathrm{Sec}$. & 0.588 & 0.601 & 0.309 & 0.315 & 0.419 & 0.429 \\
\hline & $25 \mathrm{Sec}$. & 0.563 & 0.582 & 0.296 & 0.306 & 0.402 & 0.415 \\
\hline L.S.D. at 0.05 & & 0.019 & 0.008 & 0.010 & 0.004 & 0.014 & 0.005 \\
\hline \multirow{6}{*}{ Acacia saligna } & Control & 0.590 & 0.616 & 0.310 & 0.324 & 0.421 & 0.439 \\
\hline & $10 \mathrm{Sec}$. & 0.647 & 0.646 & 0.342 & 0.340 & 0.461 & 0.463 \\
\hline & $20 \mathrm{Sec}$. & 0.620 & 0.635 & 0.326 & 0.334 & 0.442 & 0.453 \\
\hline & $30 \mathrm{Sec}$. & 0.597 & 0.610 & 0.314 & 0.320 & 0.426 & 0.435 \\
\hline & $40 \mathrm{Sec}$. & 0.573 & 0.588 & 0.301 & 0.309 & 0.408 & 0.420 \\
\hline & $50 \mathrm{Sec}$. & 0.544 & 0.561 & 0.286 & 0.295 & 0.388 & 0.400 \\
\hline L.S.D. at 0.05 & & 0.006 & 0.004 & 0.003 & 0.002 & 0.006 & 0.004 \\
\hline
\end{tabular}

Whereas, it could be concluded that the highest means in Acacia saligna plant were scored as a result of exposure time of $10 \mathrm{sec}$., where chlorophyll (a) contents were 0.647 and $0.646 \mathrm{mg} / \mathrm{g}$ in the first and second seasons, respectively. On the other hand, the lowest means in Acacia farnesiana and Acacia saligna were observed at exposure times of 25 and $50 \mathrm{sec}$. in the both seasons, respectively.

\section{Chlorophyll (b) content in fresh weight of leaves (mg/g)}

Data outlined in Table(5) reveal the effect of different exposure times from microwave on chlorophyll (b) content in fresh leaves. However, it could be concluded that the highest means in Acacia farnesiana plant were scored as a result of exposure time of $5 \mathrm{sec}$. and they were 0.360 and $0.352 \mathrm{mg} / \mathrm{g}$ in the first and second seasons, respectively. Whereas, it could be concluded that the highest means in Acacia saligna plant were scored as a result of exposure time of $10 \mathrm{sec}$. and they were 0.342 and $0.340 \mathrm{mg} / \mathrm{g}$ in the first and second seasons, respectively. On the other hand, the lowest mean in Acacia farnesiana and Acacia saligna were noticed at exposure times of 25 and $50 \mathrm{sec}$. in the both seasons, respectively.

\section{Carotenoids content in fresh leaves $(\mathrm{mg} / \mathrm{g})$}

Data obtained on the effect of different exposure times on carotenoids content in leaves were averaged in Table (5). In this connection, it could be concluded that the highest means in Acacia farnesiana plant were scored as a result of exposure time of $5 \mathrm{sec}$. and they were 0.489 and $0.478 \mathrm{mg} / \mathrm{g}$ in the first and second seasons, respectively. Whereas, it could be concluded that the highest means in Acacia saligna plant were scored as a result of exposure time of $10 \mathrm{sec}$., where they were 0.461 and $0.463 \mathrm{mg} / \mathrm{g}$ in the first and second seasons, respectively. On the other hand, the lowest mean in Acacia farnesiana and Acacia saligna were observed at exposure times of 25 and $50 \mathrm{sec}$. in the both seasons, respectively.

\section{Phenol contents in fresh leaves $(\mathrm{mg} / \mathrm{g})$}

Data obtained on the effect of exposure times from microwave on phenol contents in leaves were averaged in Table (6). The microwave treatments used revealed clear differences on phenol contents in leaves. In this connection, it could be concluded that the highest means in Acacia farnesiana plant were scored as a result of exposure time of $5 \mathrm{sec}$. and they were 3.513 and $3.566 \mathrm{mg} / \mathrm{g}$ in the first and second seasons, respectively. Whereas, it could be concluded that the highest means in Acacia saligna plant were scored as a result of exposure time of $10 \mathrm{sec}$. and they were 3.444 and $3.433 \mathrm{mg} / \mathrm{g}$ in the first and second seasons, respectively. On the other hand, the lowest means in Acacia farnesiana and Acacia saligna were noticed at exposure times of 25 and $50 \mathrm{sec}$. in the both seasons, respectively.

\section{Indole contents in fresh leaves $(\mathrm{mg} / \mathrm{g})$}

Data presented in Table (6) reveal the effect of different exposure times from microwave on indole contents in fresh leaves. However, it could be concluded that the highest means in Acacia farnesiana plant were scored as a result of exposure time of $5 \mathrm{sec}$. 
Table 6. Means of phenol and indole content and peroxidase activity of Acacia farnesiana and Acacia saligna plants as influenced by different exposure times from microwave in the two seasons of 2013 and 2014

\begin{tabular}{|c|c|c|c|c|c|c|c|}
\hline \multicolumn{2}{|c|}{ TREATMENTS } & \multicolumn{2}{|c|}{$\begin{array}{c}\text { Phenol content } \\
(\mathrm{mg} / \mathrm{g} \mathbf{F W})\end{array}$} & \multicolumn{2}{|c|}{$\begin{array}{c}\text { Indol content } \\
(\mathrm{mg} / \mathrm{g} \mathbf{F W})\end{array}$} & \multicolumn{2}{|c|}{$\begin{array}{c}\text { Peroxidase activity } \\
(\mathrm{min} / \mathrm{g} \text { FW })\end{array}$} \\
\hline Species & Exposure time & 2013 & 2014 & 2013 & 2014 & 2013 & 2014 \\
\hline \multirow{6}{*}{$\begin{array}{l}\text { Acacia } \\
\text { farnesiana }\end{array}$} & Control & 3.379 & 3.416 & 0.823 & 0.833 & 1.239 & 1.230 \\
\hline & $5 \mathrm{Sec}$. & 3.513 & 3.566 & 0.891 & 0.871 & 1.306 & 1.287 \\
\hline & $10 \mathrm{Sec}$. & 3.434 & 3.467 & 0.849 & 0.848 & 1.411 & 1.404 \\
\hline & $15 \mathrm{Sec}$. & 3.292 & 3.358 & 0.828 & 0.823 & 1.509 & 1.499 \\
\hline & $20 \mathrm{Sec}$. & 3.130 & 3.204 & 0.764 & 0.781 & 1.638 & 1.623 \\
\hline & $25 \mathrm{Sec}$. & 2.995 & 3.103 & 0.731 & 0.757 & 1.749 & 1.728 \\
\hline L.S.D. at 0.05 & & 0.080 & 0.036 & 0.025 & 0.010 & 0.033 & 0.051 \\
\hline \multirow{6}{*}{$\begin{array}{l}\text { Acacia } \\
\text { saligna }\end{array}$} & Control & 3.146 & 3.277 & 0.766 & 0.801 & 1.283 & 1.260 \\
\hline & $10 \mathrm{Sec}$. & 3.444 & 3.433 & 0.840 & 0.842 & 1.320 & 1.313 \\
\hline & $20 \mathrm{Sec}$. & 3.302 & 3.365 & 0.806 & 0.826 & 1.376 & 1.375 \\
\hline & $30 \mathrm{Sec}$. & 3.180 & 3.246 & 0.776 & 0.792 & 1.447 & 1.429 \\
\hline & $40 \mathrm{Sec}$. & 3.053 & 3.144 & 0.744 & 0.765 & 1.591 & 1.560 \\
\hline & $50 \mathrm{Sec}$. & 2.899 & 2.990 & 0.707 & 0.729 & 1.719 & 1.694 \\
\hline L.S.D. at 0.05 & & 0.034 & 0.026 & 0.008 & 0.005 & 0.084 & 0.099 \\
\hline
\end{tabular}

and they were 0.891 and $0.871 \mathrm{mg} / \mathrm{g}$ in the first and second seasons, respectively. Whereas, it could be concluded that the highest means in Acacia saligna plant were scored as a result of exposure time of $10 \mathrm{sec}$. and they were 0.840 and $0.842 \mathrm{mg} / \mathrm{g}$ in the first and second seasons, respectively. On the other hand, the lowest means in Acacia farnesiana and Acacia saligna were observed at exposure times of 25 and $50 \mathrm{sec}$. in the both seasons, respectively.

\section{Peroxidase activity $(\mathrm{min} / \mathrm{g} \mathrm{FW})$}

Data outlined in Table (6) reveal the effect of different exposure times from microwave on peroxidase activity. However, it could be concluded that the highest mean in Acacia farnesiana plant were scored as a result of exposure time of $25 \mathrm{sec}$. and they were 1.749 and $1.728 \mathrm{~min} / \mathrm{g}$ in the first and second seasons, respectively. Whereas, it could be concluded that the highest means in Acacia saligna plant was scored as a result of exposure time of $50 \mathrm{sec}$. and they were 1.719 and $1.694 \mathrm{~min} / \mathrm{g}$ in the first and second seasons, respectively. On the other hand, the lowest means of different exposure times from microwave on peroxidase activity in Acacia farnesiana and Acacia saligna were observed in control plants in the both seasons, respectively.

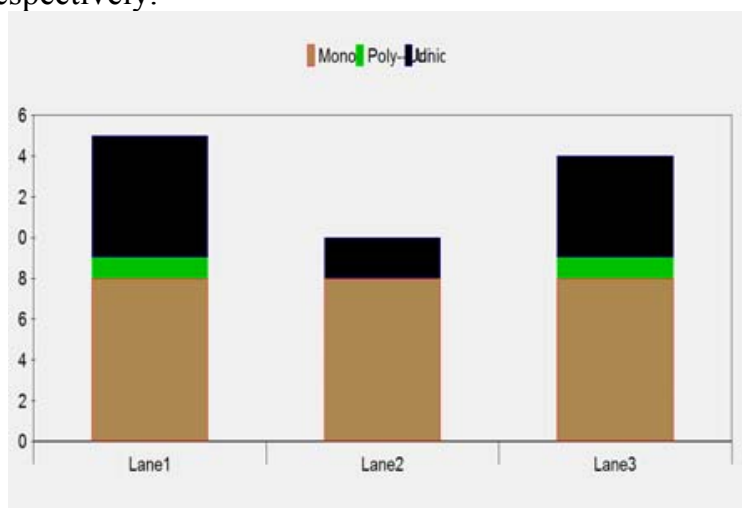

Figure 1. Protein estimation in Acacia farnesiana
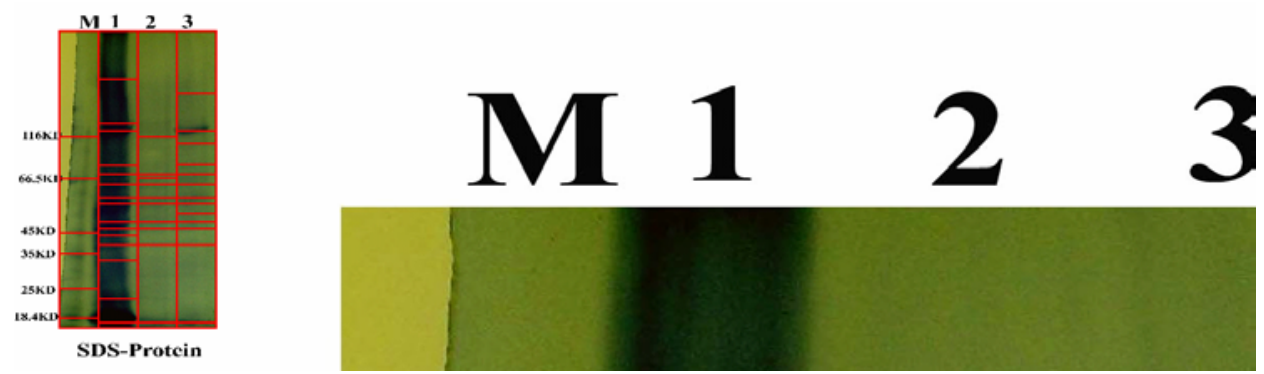

Figure 2. Protein analysis via. SDS-PAGE in Acacia farnesiana 


\section{Protein analysis (SDS-PAGE) in Acacia farnesiana}

During the experiment, the total protein was estimated in Acacia farnesiana seedlings, the best three treatments from exposure time to the microwave radiation were 5(lane 1), 10 (lane 2) and 15 (lane 3) sec. in Acacia farnesiana seedlings (Figure 1). To find out the molecular weight of the total protein SDS-PAGE analysis was used. The proteins were found to be composed of a total of 33 bands ranging from 18.4 to 116.0 KDa (Figure 2). SDS-PAGE is considered as a reliable method of genetic characterization because lectrophoretic patterns of the protein fractions are directly related to the genetic background of the proteins. In order to estimate the variability at genetic level, SDS-PAGE banding pattern of the gel using total protein was investigated.

Overall out of 33 protein bands, molecular weights of 19.5, 28.5 and $42.3 \mathrm{KDa}$ shown same protein banding pattern in seedlings, in vivo leaves and stem samples but with variation in intensities. Left behind protein banding pattern exhibited a considerable range of variability with regard to their mobilities and intensities. In seedlings protein molecular weight ranging from 18.4 to $116.0 \mathrm{KDa}$. Treatments of 5,10 and $15 \mathrm{sec}$. was similar at the most molecular weight, but from this we concluded that the numbers of protein bands which were observed showed no different between all treatments.

\section{DISCUSSIONS}

The results discussed in this section are the effects of various exposure times on seed germination, vegetative growth and chemical constituents. Decrease in seed germination is observed in all seed samples with increase in exposure time from 5 second to 25 second in Acacia farnesiana as compared to control treatment and from 10 second to 50 second in Acacia saligna as compared to control treatment.

In case of wheat, green gram and bengal gram, decrease in trend was observed for vegetative growth and chemical constituents observed with increase in exposure time as compare to control (Ragha et al., 2011).

In the case of radish seedlings, microwave may reduce the water passage across the cell membrane, closing the aquaporins and causing a reduction of growth in a turgor dependent manner. The increase of growth rate upon irradiation removal was seen during the elongation growth and the cell can partially repair damages occurred at the membrane level. There is a general consensus of opinion about the fact that microwave induces a thermal detrimental effect over biological system. In the present case we assume that the damage induced by the low power microwave exposure is non-thermal because a slight increase in temperature (up to $25{ }^{\circ} \mathrm{C}$ ) with radish seeds has been demonstrated to induce increases in germination and growth (Scialabba and Melati, 1995).

The subsequent seedling growth involves the establishment of the root and shoots systems. The hypocotyl growth is caused principally by cell expansion and/or by elongation. The low power I 0.5 $\mathrm{GHz}$ irradiation reduces the rate and percentage of germination in radish seeds and increases germination mean time, thus impairing seed germination. The reduction of hypocotyl growth (which occurs gradually when the power increases) and growth delay show the effect of MW on seed germination. performance. The hypothesis that the microwave response depends on hypocotyl development is still under investigation. The patch-clamp technique shows that the exposure to microwaves decreases the transmembrane protein channel opening in cultured chick myotubes probably because microwaves induce an alteration of intracellular enzymatic processes such as protein kinase activation (D'Inzeo et al., 1988).

Peroxides in higher plants could be classified in two major groups, according to their functions and specificity of substrate. The guaiacol peroxides have low specificity of substrate and it seems to have different peroxidative functions in the cell. The other peroxides as glutation peroxidase (Beeor-Tzahar et al., 1995) and ascorbat peroxides (Asada, 1992) are crucial for neutralization of $\mathrm{H}_{2} \mathrm{O}_{2}$, organic hydroperoxides and lipid peroxides. Up to now, guaiacol peroxides have been found in the vacuoles, cell wall, cytosol, extracelular space and corn mitochondria (Asada, 1992 and Prasad et al., 1995), whereas ascorbat peroxides are present mainly in chloroplast and partially in cytosol and glyoxisomes (Asada, 1992, Asada et al., 1993, Mittler and Zillinskas, 1993 and Bunkelmann and Trelease, 1996).

Peroxides modulates the redox equilibrium of the cell being involved in plant development (Broin et al., 2002) and the signal tranduction mediated by calcium that is necessary for induction of plant response against stress factors (Kawano, 2003). Moreover, it was allready demostrated that ascorbat peroxides, one of the peroxides from Arabidopsis is the central component in the complex of the enzymes involved in the neutralization of free radicals (Davletova et al., 2005). It has been demonstrated that ascorbat peroxides, a peroxides from mitochondria is essential for 
homeostasis and root growth in Arabidopsis under different stress conditions (Finkemeier et al., 2005).

No similar and contrary results were available in Acacia species, but in other plants, analogous results were reported in Artemisia vulgaris (Kumar and Ranjitha, 2009), Glycine max L. (Radhakrishnan and Ranjitha, 2009), and Plumbago zeylanica L. (Rout et $a l ., 2010)$. No research has been done contrary to these results. This paper presents and sheds light on the Acacia nilotica L. proteins which grow on the Nile banks of Delta region and in arid regions. Therefore, very much attention should be given to arid species since they are under severing threats these valuable plants which showed some signs as an important resource for desert ecosystem and arid environment.

\section{CONCLUSION}

The results obtained from this experiment emphasized the necessity of exposing acacia seeds to lowest time of microwave before sowing in seed beds to promote a high germination percentage and to produce uniform seedlings.

Generally, it was found that the use of microwave have an effect on the revitalization of seed germination of Acacia under different doses. For a protein analysis of Acacia seedlings, it was found that there is no genetic difference, which means that the microwave radiation dose was refresher for seed germination. Therefore, it can be used as a non-traditional means of seed germination beside to traditional methods.

\section{REFERENCES}

A.O.A.C. 1970. Association od Official Agricultural Chemists. Official Method of Analysis, P. 832-849 and 873. Washington D.C. USA.

Abeles, F.B. 1986. Plant chemiluminescence. Annu Rev Plant Physiol 37, 49-72.

Al- Helal, A. A. 1994. Electrophoretic analysis of protein and selected enzymes of Acacia seeds from Saudia Arabia. JKAU:Sci., 6:17-28.

Aref, I.M.I. 1996. The Distribution and Ecophysiology of Acacia Species in the South Western Zone of Saudi Arabia. A Ph.D. Thesis, UK: University of Edinburgh, p. 273.

Aref, I. M. I. 2000. "Morphological characteristics of seeds and seedling growth of some native Acacia trees in Saudi Arabia”. Journal of king Saud University Agriculture Science, 12(2): 77-95.

Asada, K. 1992. Ascorbate peroxidase-hydrogen peroxidescavenging enzyme in plants. Physiol Plant 85: 235-241.

Asada, K., C. Miyake, S. Sano, and K. Amako. 1993. Scavenging of hydrogen peroxide in photosynthetic organisms - from catalase to ascorbate peroxidases. In: Welinger, K.G., Rasmussen, S.K., Pene, C., Greppin, H. [eds.], Plant Peroxidases: Biochemistry and Physiology: 243-250. Geneva University Press, Switzerland.
Beeor-Tzahar, T., G. Ben-Hayyin, D. Holland, Z. Faltin and Y.A. Eshdat. 1995. A stress-associated citrus protein is distinct plant phospholipid hydroperoxide glutathione peroxidase. FEBS Lett 366:151-1555.

Broin, M., C. Santaella, S. Cuine, K. Kokou, G. Peltier and T. Joët. 2002. Flocculent activity of a recombinant protein from Moringa oleifera lam. seeds. Applied Microbiology and Biotechnology, 60, (1/2):114-119.

Bunkelmann, J.R. and R.N. Trelease. 1996. Ascorbate peroxidase: a prominent membrane protein in oilseed glyoxysomes. Plant Physiol, 110: 589-598.

Cheerma, M. S. Z. A. and S. A. Qadir. 1973. "Autecology of Acacia senegal (L.)" Willd. Vegetatio 27, 131-162.

Chen, Y.P., M. Yue and X.L. Wang. 2005. Influence of He$\mathrm{Ne}$ laser irradiation on seeds thermodynamic parameters and seedlings growth of Isatis indigotica. Plant Sci 168, 601-606.

Davletova, S., L. Rizhsky, H. Liang, Z. Shengqiang, D.J. Oliver, J. Coutu, V. Shulaev, K. Schlauch and R. Mittler. 2005. Cytosolic ascorbate peroxidase 1 is a central component of the reactive oxygen gene network of Arabidopsis. Plant Cell, 17: 268-281.

D'lnzeo, G., P. Bernardi., F. Eusebi, F. Grassi, C. Tamburello and B.M. Zani. 1988. Microwave effects on acetylcoline induced channels in cultured chick myotubes. Bioelectromagnetics, 9, 363-372.

Doran, J. C., D. J. Boland, J. W. Turnbull and B. V. Gunn. 1983. "Guide des semences d'acacias des zones sèches" [Guide to acacia seeds in arid zones]. FAO, Rome, 116p.

El-Akkad, S.S. 2004. Phylogenetic Relationship and Similarity Indices of Some Acacia Species Using Seed Protein Analysis. Intr. J. Agr. Biol., 6(3): 435-439.

Finkemeier, I., M. Goodman, P. Lamkemeyer, A. Kandlbinder, L.J. Sweetlove and K.J. Dietz. 2005. The mitochondrial type II peroxiredoxin $\mathrm{F}$ is essential for redox homeostasis and root growth of Arabidopsis thaliana under stress. J Biol Chem, 280: 12168-12180.

Gebre, G.H. and N.S. Karam. 2004. Germination of Crecis siliquastrum seeds in response to giberelic acid and startification. Seed science and technology, 32: 255-260.

Giffard, P.L. 1975. "Les gonimiers, essences des reboisement pour les regions saheliennes" [Gum trees, species for reforestation in the Sahelian region] Bois et Forets des Tropiques, 161, 3-21.

Higeg, E. and H. Inaba. 1991. Biophoton emission (ultraweak photoemission) from dark adapted spinach chloroplasts. Photochem Photobiol 55, 137-142.

Holmes, R.J., J.N.A.W. McDonald and J. Juritz. 1987. Effects of clearing treatment on seed bank of the Alinene invasive shrubs Acacia saligna and Acacia Cyclops in the southern and south Western Cape, South Africa. Journal of Applied Ecology, 24: 1045-1051. 
Howell, C.R., L.E. Hanson, R.D. Stipanovic and L.S. Duckhaber. 2000. Induction of Terpenoid synthesis in cotton roots and control of Rhizoctoniasolani seed treatment with Trichoderma virens. Phytopathology, $35: 49-60$

Hu, X.R., H.L. Li and Y.P. Jiang. 1996. Effect of microwave and hot treatment on the seeds germination of Oryza sativa. Acta Agron Sin 22, 220-222 (in Chinese with an English abstract).

Jackson, N. L. 1958. Soil Chemical Analysis. Constable. Ltd. Co., London, 498 p.

Kaul, R.N. and M. S. Manohar. 1966. "Germination studies on arid zone tree seeds". I. Acacia senegal Willd. The Indian Forester, 92: 499-503.

Kawano, K. 2003. Character displacement in stag beetles (Coleoptera, Lucanidae). Annals of the Entomological Society of America, 96:503-511.

Kumar, P.S., B.D. Kumari Ranjitha. 2009. In vitro and In vivo Identification of variation in protein expression in Artemisia vulgaris L. Adv. Biol. Res., 3(5-6): 63-70.

Laemmli, U.K. 1970. Cleavage of structural proteins during the assembly of the head of bacteriophage T4. Nature, 227: 680-685.

Larson, P., A. Harbo, S.Klungsour and T.A. Ashein. 1962. On the biogenesis of some indole compounds in Acerobacter xylium. Physiol. Plant. 15: 552-565.

Lowry, O.H., N.J. Rosebrough, A.L. Farr and R.J. Randall. 1951. Protein measurement with the Folin Phenol reagent. J. Biol. Chem., 193: 265-275.

Mabberley, D.J. 1997. The Plant Book: A Portable Dictionary of the Vascular Plants, 2nd edition. Cambridge, UK: Cambridge University Press.

Mittler, R. and B.A. Zilinskas. 1993. Detection of ascorbate peroxidase activity in native gels by inhibition of the ascorbate-dependent reduction of nitroblue tetrazolium. Anal. Biochem, 212:540-546.

Mohapatra, H.P. and S.P. Rath. 2005. In vitro studies of Bacopa monnieri -an important medicinal plant with reference to its biochemical variations. Indian J. Exp. Biol., 43(4): 373-376.

Nornai, R. 1982. Formula for determination of chlorophyll pigments extracted with N.N. dimethylformide. Plant Physiol., 69: 1371-1381.

Prasad, T.K., M.D. Anderson and C.R. Stewart. 1995. Localization and characterization of peroxidases in the mitochondria of chilling acclimated maize seedlings. Plant Physiol, 108: 1597-1605.
Radhakrishnan, R. and B.D. Ranjitha Kumari. 2009. Changes in Protein Content in Micropropagated and Conventional Soybean Plants (Glycine max (L.) Merr.). World J. Agric. Sci., 5(2): 186-189.

Ragha, L., Mishra S., V. Ramachandran and M.S. Bhatia. 2011. Effects of Low-Power Microwave Fields on Seed Germination and Growth Rate. Journal of Electromagnetic Analysis and Applications, 3:165-171.

Rao, Y.V.S., N.V.K. Cnakravarthy and B.C. Dpanda. 1989. Effect of microwave irradiation on germination and initial growth of mustard seed. Indian J Agron 34, 376-379.

Rashmi, M., S. Nanda Nayak and G.R. Rout. 2004. Studies on genetic relatedness of Acacia tree species using RAPD markers. Biologia, Bratislava, 59(1): 115-120.

Roussel, J. 1984. "Gemination des semences forestieresUtilisation de acid sulfurique concentre en pretraitement des principales especes, soudano-saheliennes et exotiques" [Germination of tree seeds- Use of concentrated sulphuric acid in the pretreatment of principal Saheline, SudanoSahelian and exotic species]. Centre National de Resherches Forestieres, Dakar, 5p.

Rout, J.R., S. Kanungo, R. Das and S.L. Sahoo. 2010. In vivo protein profiling and Catalase Activity of Plumbago zeylanica L. Nat. Sci., 8(1): 87-90.

SAS Institute. 2002. SAS user guide and program 20 version 9.0.38. cary, NC27513.

Scialabba, A. and M.R. Melati. 1995. Low temperature induced delay in the germination, growth and xylem differentiation of radish seedlings. Atti Accademia di Scienze, Lettere ed Arti di Palermo, s.V, XV, 147-170.

Selim, H.H.A., M. A. Fayek and A.M. Sweidan. 1978. Reproduction of Bricher apple cultivar by Layering Annals of Agric. Sci, Moshtohor, 9:157-166.

Sharma, A. 2006. In vitro morphogenetic studies of Boerhaavia diffusia L. Ph.D. Thesis University of Rajasthan. Studier FW (1973). Analysis of bacteriophage T7 early RNAs and proteins on slab gels. J. Mol. Biol., 79: 237-248.

Snedecor, G. and W.Cochran. 1980. Statistical Methods.7 Ed., Iowa state Univ. Press, Iowa, USA, ISBN 9780815381560, 97808153815602.

Studier, F.W. 1973. Analysis of bacteriophage T7 early RNAs and proteins on slab gels. J. Mol. Biol., 79: 237-248.

Xiang, Y. 1995. Laser Biology (in Chinese), Changsha: Hunan Science and Technology Press, 124-127. 


\section{الملضص العري

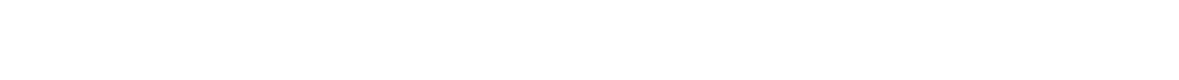 \\ (Acacia saligna and Acacia farnesiana) \\ حنان عز الدن إبراهيم ، حنان غالى الفضالى، نادر لحمد الشنهورى}

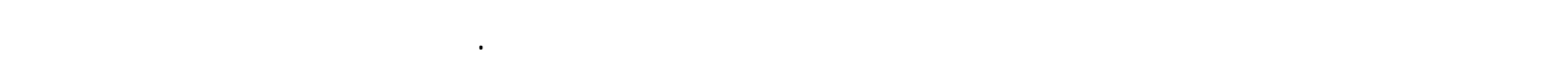

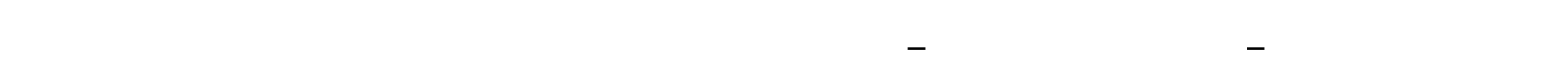

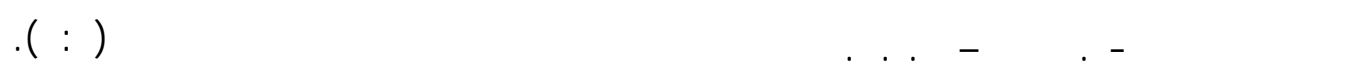

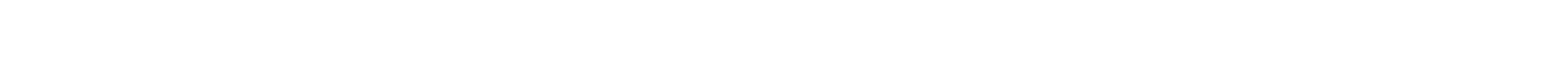

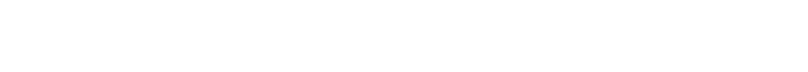

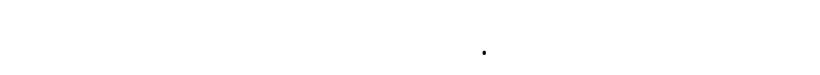

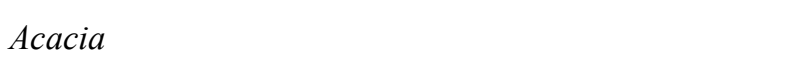
farnesiana

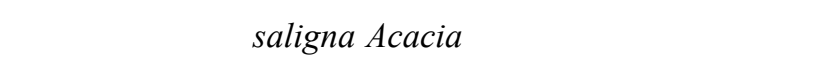
من لثشعة الميكرووف في كلا الموسمين على التوالى.

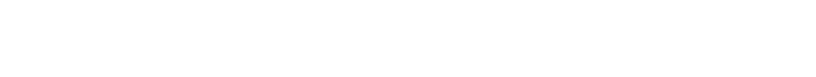
لنوعى الألكلسيا farnesiana Acacia تعريض بذور farnesiana Acacia لأشيعة المكيرووف لمديا

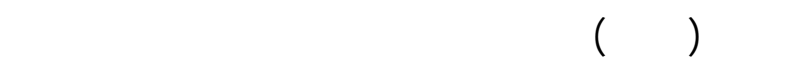

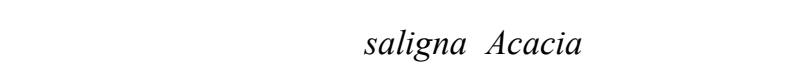

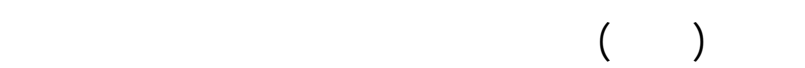

